easy and low route is possible. Thus the first step in a good and easy trade route out of India is secured, and secured here alone.

From Nongyang the usual route for traders is vita Namyung, Songphú village in a level plain of same name, thence via the Turong villages and rolling slopes of the upper part of the Dinoi valley and the low Kako hills dividing it from the Irawadi. On crossing this latter two routes are available, one up the Shoemai Kha and Sittang flat country, the other more east, turning the southern extremity of the Goulang si gong range, that coming down from the north divides Burma from China. Such a route would also pass round the heads of the Taeping, Shueylí, and Salwín valleys, and leave but one large stream, the Mikong, to cross ere reaching the Yangtse Kiang, at a point near Li kiang fu, navigable at all seasons - the main artery of China. The total distance of such a route from the plains of Asam at the Namphuk to the Yangtse I estimate at 300 miles to 350 , including windings, and to clear out a serviceable bridle path or fair weather road on this I estimate would cost but Io, ,ool. The present path for long distances is a mere jungle track often obstructed by fallen trees; small deep gullies necessitate long détours. Were some of the jungle removed and fallen trees, a few strong logs felled over the little streams would make a good commencement.

I need not say much regarding the advantages of such a route, if available. For political reasons it was once thought desirable to discourage direct intercourse between India and China; but that day has departed. England is now one of the three great Asiatic powers, and the time has arrived when we must not only examine our passes west and east, but cultivate as far as possible a profitable and peaceful intercourse with China. The state of Upper Burma (once a Chinese province) simply renders this question urgent. At a time also when Australia and America are invaded by such hordes of cheap labourers, labour paying heavily for its own transport to distant and overstocked markets, we see Asam-close to the labour source-suffering from a want of it, and planters paying Rs. 80 and Rs. Ioo per head ere they can employ labour of a very inferior stamp.

S. E. PEAL

\section{KARL FRIEDRICH MOHR}

$\mathrm{BY}$ the death of Dr. Mohr, of Bonn, which is just announced, the science of chemistry has lost a worker whose labours have extended over nearly half a century, and have led to great and valuable results.

Dr. Karl Friedrich Mohr was born at Coblenz in November, 1806. His earliest work was devoted to the continuation of the Pharmacopœia, established by Geiger. The work by which he will be best remembered is the "Lehrbuch der chemisch-analytische Titrirmethode," which appeared in 1855 and 1856 , the second, and considerably enlarged edition, appearing in 1862 . His published papers, which are very numerous, arrange themselves in two classes mainly, those devoted to meteorology and those having a bearing on volumetric analysis. Ground-ice, the earliest information about ozone, St. Elmo's fire are among the subjects of his earliest, and among his later the lower ends of lightning conductors, hail and rain, and confirmation of his theory of the formation of hail. The other more numerous class of papers on analysis extend over nearly fifty years. His cxamination of the method of separating copper and silver appeared in Liebig's Annalen der Chemie in I832, to be followed by others on the condensation of chlorine, on Marsh's method, preparation of barium hydrate, the reduction of silver chloride, the action of the air on arsenides, and thirty years later on the value of indirect. analysis, on nitrate determinations, the estimation of the different oxides of manganese, analysis without the use of weights, examination of a method of determining the specific gravity of liquids with a watch, phosphoric acid determinations, \&c.

About ten years ago he published his "Allgemeine Theorie der Bewegung und Kraft," and shortly afterwards "Mechanische Theorie der chemischen Affinität."

About four years ago he sent to Liebig's Annalen der Chemie a curious paper on the nature and mode of origin of meteorites. He finds that all the silicates present in meteorites contain a little water, and when heated strongly or fused have a decreased specific gravity; that some meteorites contain organic compounds like certain terrestrial carbon compounds, but that meteoric iron contains no combined carbon.

\section{THE INTERNATIONAL ASTRONOMICAL SOCIETY}

THE eighth Annual Meeting of this Association was held at Berlin on September 5 to 8. The sixth and seventh meetings of the Society were held at Leyden (1875) and at Stockholm (1877). At the latter place Berlin was selected for the next general meeting, to be held in the present year. This city being more centrally situated for the greater part of the members than Leyden or Stockholm, it was expected that a rather large proportion of the Fellows of the Society would meet there; and so it has proved. There were present the following sixty-one astronomers, mechanicians, and opticians :-Abbe (Jena), Auwers (Berlin), Baeker (Nauen), de Ball (Gotha), H. G. van de Sande Bakhuyzen (Leyden), Bamberg (Berlin), Bansa (Frankfort), Becker (Berlin), Behrmann (Elsfeth), Bergmann (Berlin), Boguslawski (Berlin), Bruhns (Leipzig), Bruns (Berlin), Denker (Hamburg), Drechsler (Dresden), Elkin (New Orleans), Engelmann (Leipzig), Förster (Berlin), Franz (Königsberg), Friesach (Graz), Fuess (Berlin), Galle (Breslau), Gyldèn (Stockholm), Hasselberg (Pulkowa), Huggins (London), Kempf (Potsdam), v. Knorre (Berlin), Kreutz (Bonn), Krüger (Gotha), Küstner (Strassburg), Lehmann (Berlin), Lehman-Filhès (Berlin), Lohse (Potsdam), Maywald (Berlin), Merz (Munich), Möller (Lund), Miiller (Potsdam), Neumeyer (Hamburg), Oppenheim (Berlin), Oudemans (Utrecht), Palisa (Pola), Pechüle (Copenhagen), v. Plaenckner (Gotha), 'Pihl (Christiania), Reichel (Berlin), O. Repsold (Hamburg), Romberg (Pulkowa), Rosèn (Stockholm), Rümker (Hamburg), Safarik (Prag), Schönfeld (Bonn), Spörer (Potsdam), Tiede (Berlin), Tiele (Copenhagen), Tietjen (Berlin), Valentiner (Mannheim), Vogel (Potsdam), Wanschaffe (Berlin), Winkler (Leipzig), Winnecke (Strassburg), Wittstein (Leipzig). Hence, besides forty-six Germans, there were present three Fellows from Austria, three from Sweden, two from Holland, two from Denmark, two from Russia, and one each from America, England, and Norway.

The Council, composed of Prof. Kriger, President, Prof. Förster, Prof. Gyldèn, Prof. van de Sande Bakhuyzen, Vice-presidents; Prof. Bruhns, Librarian, Director Auerbach, Treasurer; Secretaries, Professors Schönfeld and Winnecke, met on September I, to consider the matters to be submitted to the meeting.

The day before the opening of the general meeting there was unveiled at the Berlin Observatory, in the presence of Encke's son and daughter, surrounded by many distinguished guests, the bust of the distinguished astronomer, who founded the new observatory at Berlin, and rendered it famous by incessant labour. The bust was made by the celebrated artist, Afinger. Prof. Förster, to whose exertions this acknowledgment of his predecessor is due, recalled to the assembled guests in spirited words the great astronomer's principal merits.

On September 5 the general meeting was opened at ten o'clock in the morning by Prof, Krüger, in the lecture hall of the Royal Academy of Sciences. The Minister for Public Instruction, Herr von Puttkammer, welcomed 
the assembly in the name of the Prussian Government, and said that he hoped the new arrangements at the Royal Observatory in Berlin, and the newly-finished Astro-Physical Observatory at Potsdam would be objects worthy of the attention of foreign astronomers.

The President, after having thanked the Minister for Public Instruction, gave a summary of the number of Fellows of the Society. At Stockholm the Society had 258 Fellows; nine of these died, one left the Society, and thirty-five new Members were provisionally admitted by the Council, the number of Fellows being therefore at present 283. It is well understood that by the bye-laws of the Society there are no Associates or Honorary Members. Prof. Krïger then read an historical account, composed by the Council, of those transactions which induced Herr Struve, Director of the Imperial Observatory at Pulkowa, to resign, last year, the office of president. Then the Reports on the business during I $877-79$ were read.

The treasurer (Herr Auerbach) not being able to be present at the meeting, Prof. Bruhns read his report on the expenses and the income of the Society. Besides the stock of the various publications, the Vierteljahrsschrift and some astronomical instruments, the Society has invested about 40,000 marks.

The librarian (Prof. Bruhns) gave a summary of books received, and stated that a catalogue of all the books had been prepared, and that it was passing through the press.

The secretary (Prof. Winnecke) reported on the publications. There have been printed and distributed to the Fellows since the Stockholm meeting, nine Hefte of the Vierteljahrsschrift, viz., vol. xii. Heft 4, vol. xiii. and vol. xiv. Hefte 1-3; he mentioned that it had been tried to add to the biographical notices on deceased astronomers their portraits in photography. Of the quarto publications there had just appeared :--

No. xiv. - "Fundamental-Catalog für die Zonenbeobachtungen am nördlichen Hirnmel. Herausgegeben im Auftrage der Zonencommission der Astron. Gesellschaft von A. Auwers."

No. xv, -E. Hartwig, "Untersuchungen über die Durchmesser der Planeten Venus und Mars nach Heliometermessungen auf der provisorischen Universitätsternwarte zu Strassburg, mit Hinzuziehung der anderweitigen vorhandenen Mikrometerbeobachtungen."

The "Ephemeriden der Fundamentalsterne für die Zonenbeobachtungen" for the year 1880 , published by the Redaction of the Berliner Jahrbuch, in co-operation with the Society, has just been issued. Further, two small volumes have been printed for private circulation, the one containing the Minutes of the Council Meetings, the other giving extracts of the Transactions of the Council by letter.

The reading of the reports was interrupted by Prof. Förster inviting the members to visit, in the afternoon the Royal Observatory. He gave a lucid exposition of the arrangements of the newly reconstructed observing xooms. He had had in view to get the temperature in the meridian room as far as possible identical with the outer one. There was constructed a new cupola for an equatorial of 8 feet, and a revolving roof for a new transit, to be used in different azimuths.

For the next day Prof. Förster proposed to visit Potsdam. There the just finished Astro-Physical Observatory should be inspected, and in the evening there would be a soirée given by the Government at Glienicke. Prof. Bruhns then read the report on the progress of cometary astronomy; in connection with it Prof. Gyldèn made some remarks on the computations by Dr. BackIund, of Pulkowa, of the absolute perturbations of Encke's comet by his new method.

There were proposed as places for the next meeting in $188 \mathbf{1}$, Strassburg (Winnecke), Graz (Friesach), Brussels (Gyldèn); the election took place on the day following. Prof. Winnecke then gave, in support of his invitation to Strassburg, a detailed account of the new observatory now nearly finished there, and illustrated it with many drawings, representing the buildings, and explaining the manner of constructing the domes and laying the foundation for the pillars. There had to be provided observing rooms for the equatorial (object-glass I 8 Paris inches), an orbit-sweeper ( 6 inches), the Repsold meridian-circle ( 6 inches), the altazimuth ( 5 inches), the Cauxoix-transit ( 5 inches), and different smaller instruments. There were a great many peculiarities differing from existing observatories, and Prof. Winnecke was very anxious to know if these innovations would turn out to be improvements.

Dr. Hasselberg (Pulkowa) spoke of the light emitted by gases induced by electricity and low temperature.

Dr. Drechsler (Dresden) reported on the collections of the Mathematical Saloon at Dresden, and distributed copies of a catalogue of them.

Prof. Saffarik (Prague) spoke on his observations on the colour of stars, principally on those of $a$ Ursæ maj., the colour of which is said to be considerably and periodically variable. His own results do not confirm at all the supposed variability. This matter was then discussed between Herren Oudemans, Saffarik, and Winnecke.

Prof. Förster laid before the meeting (I) a volume, just published, in German, containing the observations of Dr. v. Konkoly at O'Gyalla ; (2) different drawings of nebula from Herr Tempel at Arcetri ; (3) an account by Dr. v. Konkoly of the new observatory, established in Hungary, at Kalocsa, by the Archbishop of Haynald. The director of this new observatory is Dr. Braun, well known by his attempts to register automatically the transits of stars.

September 6.--Prof. Auwers (Berlin) read the report on the principal undertaking of the Society, to fix by exact observation the places of all the stars down to the 9th magnitude, contained in Argelander's "Durchmusterung des nördlichen Himmels," the number of which is about 200,000 . The observatories either busily engaged or having finished the part allotted to them in this work are: Nicolajew (Russia), Albany (U.S.A.), Leipzig (Germany), Lund (Sweden), Berlin (Germany), Leyden (Holland), Bonn (Germany), Helsingfors (Finland), Dorpat (Russia), Christiania (Norway), Kasan (Russia). The printing of some parts of the Catalogue will probably commence very soon, and it is to be hoped the grand work will be finished in a few years.

As the place for the next meeting (188I) the votes were nearly unanimous for Strassburg.

Prof, Gyldèn (Stockholm) expounded a new theory of the variability of stars, trying to reduce the problem to mechanical principles and expounding his views of overcoming the mathematical difficulties.

Dr. Schröder (Hamburg) gave an account of his proceedings in practical optics, aided by theoretical researches. As the hour of leaving for Potsdam was near, he delayed the exhibition of some specimens of his skill to Monday.

September 8.-According to the new elections made at the beginning of this meeting, the Council of the Society is composed, for the period $1879-8 \mathrm{I}$, as follows :President, Prof. Krüger (Gotha); Vice-Presidents: Prof. Auwers (Berlin), Prof. Gyldèn (Stockholm), Prof. van de Sande Bakhuyzen (Leyden); Secretaries: Professors Schönfeld (Bonn), Winnecke (Strassburg); Librarian, Prof. Bruhns (Leipzig); Treasurer, Director Auerbach (Leipzig)

Prof. Tietjen (Berlin) read the report on the small planets, followed by a discussion between Herren Bruhns, Förster, and Oudemans.

Director Palisa (Pola) moved :--"To invite the Council of the Society to consider the means of arranging a better and more economical organisation of the present system of telegraphic announcement of new astronomical dis- 
coveries." This motion, after some discussion, was carried unanimously.

Dr. Schröder (Hamburg) then finished the communication begun at the previous meeting. Herren Abbe (Jena), Saffarik (Prague), Brubns (Leipzig), Winnecke (Strassburg), took part in the discussion on it. Prof. Oudemans (Utrecht) reported on the Gaussian object-glass of the Utrecht Observatory. Dr. Huggins (London) gave an account of his results in photographing star-spectra, and showed some of them to the meeting. Prof. Bruhns (Leipzig) exhibited drawings of nebula and neighbouring stars made by students of the University with small telescopes. Prof. Abbe (Jena) gave an elaborate account of his important theoretical and experimental researches in optics, followed by a discussion between him and Herren Förster and Winnecke. Prof. van de Sande Bakhuyzen (Leyden) explained his researches upon the dependance of the personal error in transit observations from the magnitude of the stars. Prof. Schönfeld (Bonn) reported on the progress of his "Durchmusterung" of the southern heavens. There is finished in observation at present about two-thirds of the whole work.

After a vote of thanks to the Prussian Government, the Royal Academy of Sciences, and the Berlin astronomers, the meeting of the International Astronomical Society was closed late in the afternoon.

A. WINNECKE

\section{INFLUENCE OF ELECTRICITY ON VEGETATION}

SEVERAL months ago, it will be remembered, $M$. Grandeau described to the Paris Academy experiments made by himself and M. Leclerc at Nancy and Mettray, whence it appeared that flowering and fructification are retarded and impoverished if plants are excluded from the influence of atmospheric electricity-as by being inclosed in a metallic cage, or being near trees or other objects which may carry off electricity of the air.

Recently $M$. Naudin has repeated the experiments referred to, but with other plants and in a different climate, and, without wishing to contradict the conclusions arrived at for tobacco and maize (the plants that had been experimented with), he is led to regard the declarations made as too general, inasmuch as his results are almost exactly opposite to those obtained by MM. Grandeau and Leclerc.

It was at Antibes, in the large botanical garden formed by the late Thuret (now Government property), that M. Naudin made his experiments. He bad an iron quadrangular cage made, covering a surface of fifty-one square decimetres, and about one metre in height; the frame carried points above (like small lightning conductors), and was covered with iron netting, the lozenge-meshes of this being $0.09 \mathrm{~m}$. long by $0.054 \mathrm{~m}$. broad (it intercepted more light than M. Grandeau's, but this is thought insignificant). The cage was placed in a kitchen garden, and the plants it was made to inclose were kidney beans, lettuce, tomato, and herbaceous cotton (the last alone being sown as seed). In the same garden, at 7 metres distance, plants as like the others as possible were planted, and cotton seeds of the same kind sown, but without a cage-cover. The soil was perfectly homogeneous throughout, and all parts of the plot vere equally exposed to sunlight, dew, and rain. The experiment began on May 25.

For a fortnight there appeared no sensible difference between the two portions ; but about the middle of June it was remarked that the plants of the cage were stronger than those in the open air, and this difference became more pronounced as time went on. The plants, indeed, progressed side by side in this sense, that the flowerings were absolutely contemporaneous in the plants of the same species ; and it was the same with formation and maturation of fruits. But it was quite otherwise with the quantity of vegetable matter produced in a given time and on the same extent of soil, and this difference was entirely in favour of the caged plants.

We may take the figures tabulated by M. Naudin for the tomato (examined August I4), as a good example of this :-

\begin{tabular}{|c|c|c|c|}
\hline & $\begin{array}{l}\text { Tomato in } \\
\text { open air. }\end{array}$ & & $\begin{array}{l}\text { mato under } \\
\text { the cage. }\end{array}$ \\
\hline Length of the principal stem ... & $0.80 \mathrm{~m}$ & $\cdots$ & rom. \\
\hline $\left.\begin{array}{l}\text { Total weight of the plant cut } \\
\text { at the level of the ground, } \\
\text { fruits included ... ... ... }\end{array}\right\}$ & $2.072 \mathrm{~kg}$ & $\cdots$ & $3^{\circ} 754 \mathrm{~kg}$ \\
\hline $\left.\begin{array}{c}\text { Number of ripe fruits and } \\
\text { green fruits of all sizes }\end{array}\right\}$ & 37 & $\cdots$ & 83 \\
\hline $\begin{array}{c}\text { Weight of the whole of the } \\
\text { fruit detached from } \\
\text { plant } \\
\ldots\end{array}$ & $\mathrm{I} \cdot 80 \mathrm{~kg}$. & $\cdots$ & $2.162 \mathrm{~kg}$. \\
\hline
\end{tabular}

The other plants gave a similar testimony in favour of the withdrawal of atmospheric electricity. Thus, the total weights of the bean plants were respectively $\mathrm{r} 42 \mathrm{gr}$. and $167 \mathrm{gr}$. ; and of the lettuce $337 \mathrm{gr}$. and $427 \mathrm{gr}$. The cotton plants were weakly (as there had been no watering), but their evidence was in the same line as that of the others.

The injurious influence, which, according to $\mathrm{M}$. Grandeau's theory, trees exert on plants in their neighbourhood, by withdrawing atmospheric electricity, is also considered by $M$. Naudin to be only a special case. Besides, it is easy to ascribe to this withdrawal what is merely the result of the shade cast by trees, and especially of the exhaustion and desiccation of the ground by their roots, which often extend to a great distance. On the other hand there are many plants which seek the neighbourhood of trees, and which even thrive only under their shadow, and these, probably, must be adapted to a diminution of atmospheric electricity. At the Villa Thuret, M. Naudin remarks, there are several lawns quite inclosed by trees (pines, firs, cypresses, \&c.), many of which are adult and of pretty good size. These lawns contain, besides their grass, thousands of anemones (A. pavonina, A. cyanea, A. stellati), some of pure race, others hybrid, whose flowers present all shades of red, rose, purple, white, and blue. The appearance is striking when the flowers come out in March or April. The flowering is not entirely contemporaneous throughout the lawn; it begins near the trees, and gradually extends to the middle of the lawn; the difference of time between these two extremes being twelve to fifteen days: Moreover, the anemones nearest to the trees, in addition to their relative precocity, are generally stronger and taller, and have broader, perhaps more brightly coloured corollas, than those in the middle of the lawn.

From the observations described, M. Naudin is disposed to think the question as to the influence of atmospheric electricity on plants is complex, and far from being decided as yet. This influence, in all probability, is modified first by the very essence of the species, which must behave, in regard to atmospheric electricity, as to other agents of vegetation, that is to say, in very diverse manners; then it is modified by climate, season, temperature, degree of light, dry or wet weather, perhaps alsa by the geolngical structure or mineralogical composition of the ground, the layers of which, suparficial or deep, may not be equally conductive of electricity. It is possible, lastly, that all tree species may not alike withdraw the electric effluves of the atmosphere, and this is a point necessary to be determined. Until these numerous and so obscure conditions of the problem before us are suffi. ciently known, we should regard as premature any conclusion which is applied to the whole, or even only to the generality of the vegetable kingdom.

\section{THE DIFFUSION OF LIQUIDS}

$\mathrm{T} \mathrm{T}$ is fortunate that various branches of the work with which Graham's name will always be connected are now attracting the attention of physicists. At the 